\title{
QXFOR2
}

\section{THE END OF THE WORLD} An Introduction to Contemporary Drama

MAURICE VALENCY, Director of Academic Studies, The Juilliard School. Depicting the crisis of faith at the turn of the century, Valency shows how Symbolism, in all its various manifestations, developed as a revolutionary movement rejecting Realism and affecting all forms of art. He traces the artistic and emotional ferment generated by this movement in the theater through an examination of the work of its most significant dramatic representatives-Mallarmé, Maeterlinck, Pirandello, Giraudoux, Artaud, Ionesco, and Beckett. 480 pp. , $\$ 19.95$

\section{A SOUTHERN RENAISSANCE}

The Cultural Awakening of the American South 1930-1955

RICHARD H. KING, Professor of Philosophy and History, University of the District of Columbia. William Faulkner, James Agee, Thomas Wolfe, Cleanth Brooks, and C. Vann Woodward are just a few of the writers discussed in this study of the outpouring of fiction, poetry, memoirs, and historical writing that came out of the American South from 1930-1955. King shows how these writers transcended plantation culture, the Civil War, Reconstruction, and racial reaction to raise Southern tradition to historical awareness, making way for the vast changes in Southern culture in the 1960's and '70's. 320 pp., $\$ 13.95$

\section{IMAGINING AMERICA}

PETER CONRAD, Fellow of Christ Church, Oxford. "Cruelly perceptive, witty, frighteningly intelligent, and overwhelmingly eloquent. Imagining America is a penetrating inquiry into the challenge America poses to the British imagination. In probing this subject, Conrad displays a perceptiveness and intelligence that all might envy. He has written a brilliant, funny, and eloquent book and shown what criticism can do when it really looks at things."-Paul Fussell

$336 \mathrm{pp}, \mathbf{1 2 . 9 5}$

\section{NATURE AND CULTURE}

American Landscape and Painting, 1825-1875

BARBARA NOVAK, Chairman of the Art History Department, Barnard College, Columbia University. "Barbara Novak's writing has had singular and wide influence on the field of American art scholarship. Her new book probes the crucial area of cultural ideas with both a depth and breadth that are bound to affect our thinking afresh."-John Wildmering, National Gallery of Art. "The most important contribution to the understanding of 19th-century American art that has been written in our generation."-John I. H. Baur, Director Emeritus, Whitney Museum of American Art 304 pp., 150 black \& white illustrations, 8 page color insert, $\$ 30.00$

Prices subject to change.

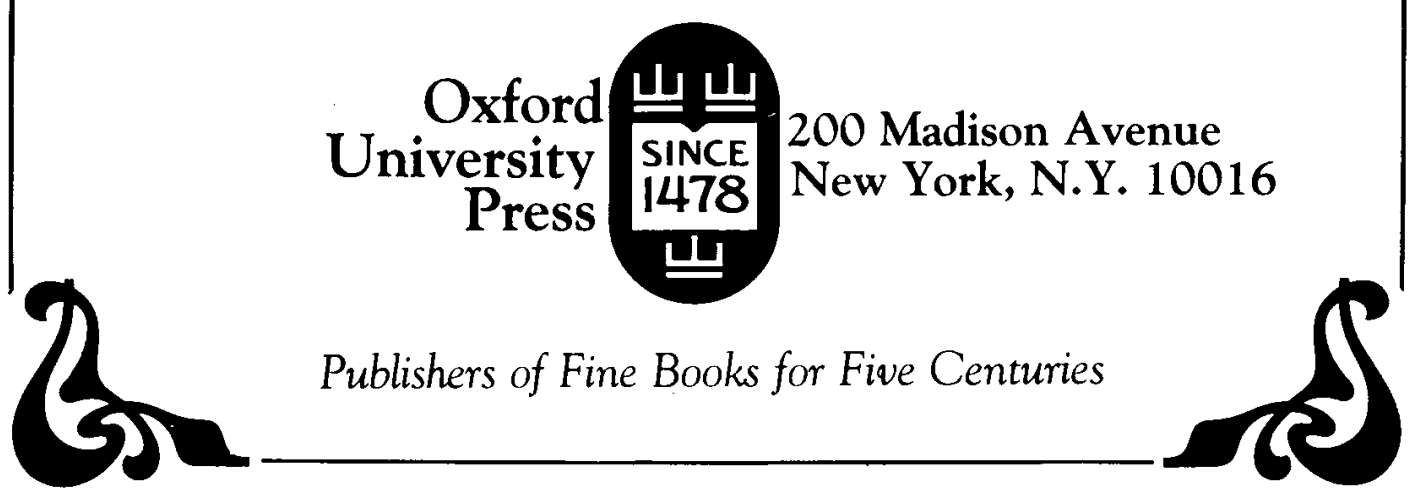




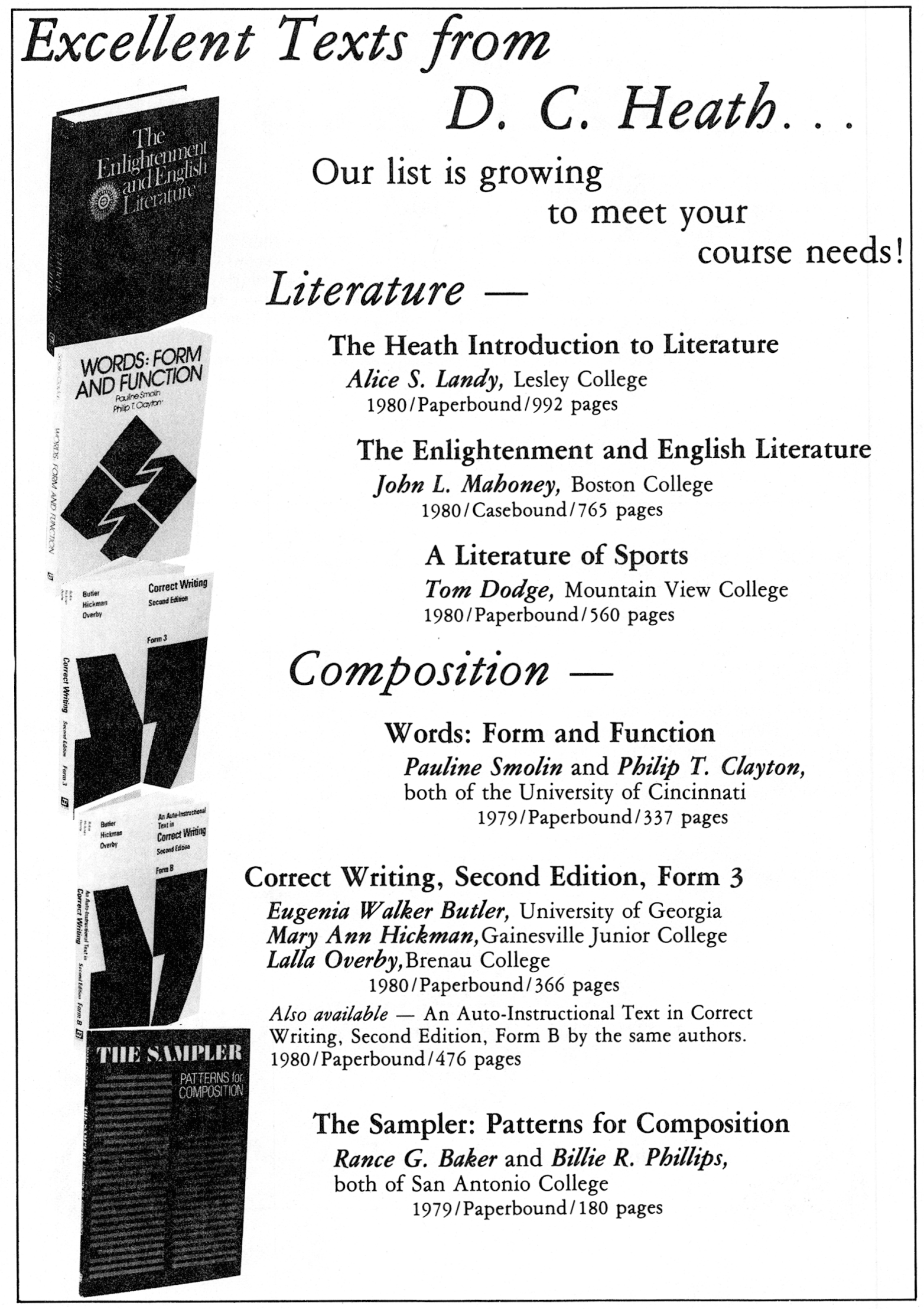




\section{Humanities}

\section{The Humanities: Cultural Roots and Continuities}

\section{Volume I: Three Cultural Roots - 448 pages}

\section{Volume II:}

The Humanities and

the Modern World -

400 pages

$1980 /$ Paperbound

Mary Ann Frese Witt, North Carolina State University Charlotte Vestal Brown, Duke University Roberta Ann Dunbar, University of North Carolina, Chapel Hill

Frank Tirro, Duke University; Ronald G. Witt, Duke University

\section{French -}

Franc-Parler, Second Edition Simone Renaud Dietiker,

San Jose State University

1980/Casebound/464 pages

Cahier d'exercises supplementaires/Manuel de

laboratoire. Livre du maitre. Tape Program (cassettes or reels). Tapescript.

Aujourd'hui, Second Edition Maresa Fanelli, Lafayette College Michel Guggenheim, Bryn Mawr College $1980 /$ Casebound/ 544 pages

Cahier d'exercises supplementaires/Manuel de laboratoire. Tape Program (cassettes or reels). Tapescript.

\section{German -}

Spoken German, Second Edition Renate Hilller

1980/Paperbound/304 pages

\section{Italian -}

Beginning Italian, Third Edition Vincenzo Cioffari, Boston University 1979/Paperbound/288 pages

\section{Spanish-}

Enfoques: Temas de comentario oral y escrito

Mireya Camurati, State University of New York at Buffalo

With the assistance of Dorothy B. Rosenberg 1980/Paperbound/240 pages est.

\section{Basic Spanish Grammar}

Ana C. Jarvis, San Bernardino Valley College Raquel Lebredo, California Baptist College Francisco Mena, California State University, Chico 1980/Paperbound/ 256 pages est.

Applied Spanish Workbooks available in Business and Finance, Medical Personnel, Oral Communication, and Law Enforcement Personnel.

De aquí y de allá: Estampas del mundo hispánico

Eduardo Zayas-Bazán and Manuel Laurentino Suárez, both of East Tennessee State University 1980/Paperbound/224 pages

For details or sample copies, call us toll free: 800-225-1388. In Massachusetts, call collect: 617-862-6650, ext. 1344 .

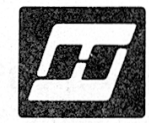

HEATH

\section{C. Heath and Company}

Lexington, Massachusetts 02173 


\section{Books from University Presses}

AMERICAN LITERATURE AND LITERARY CRITICISM

\section{A Confederacy of Dunces}

By John Kennedy Toole

Louisiana State, March 1980, $\$ 13.95$

\section{The Dream of Arcady}

Place and Time in Southern Literature

By Lucinda H. MacKethan

Louisiana State, April 1980, $\$ 20.00$

From the Sunken Garden

The Fiction of Ellen Glasgow, 1916-1945

By Julius Rowan Raper

Louisiana State, March 1980, $\$ 19.00$

Language as Being in the Poetry

of Yvor Winters

By Grosvenor E. Powell

Louisiana State, March 1980, $\$ 13.95$

\section{Mayday}

By William Faulkner

Notre Dame, January 1980, $\$ 8.95$

The Wayward and the Seeking A Collection of Writings by Jean Toomer Edited by Darwin T. Turner

Howard, March 1980, $\$ 14.95$

ENGLISH LANGUAGE LITERATURE AND LITERARY CRITICISM

The Five Square City

The City in the Religious Imagination

By James Dougherty

Notre Dame, March 1980, \$12.95

\section{Such Holy Song}

Music as Idea, Form, and Image in

the Poetry of William Blake

By B. H. Fairchild, Jr.

Kent State, April 1980, $\$ 15.00$

ASIAN LITERATURE AND LITERARY CRITICISM

\section{Chieko and Other Poems}

By Kotaro Takamura

Hawaii, March 1980, \$10.95

Tales of Japanese Justice

By Saikaku Ihara

Hawaii, February 1980, $\$ 6.50$ p.
ROMANCE LANGUAGES LITERATURE AND LITERARY CRITICISM

Collaboration et Originalité chez la Rochefoucauld

By Susan Read Baker

Florida, May 1980, tentatively $\$ 6.00$

La Correspondance d'Émile Zola Tome II By B. H. Bakker

Montréal, 1979, $\$ 48.00$

The Fool of God

Jacopone da Todi

By George T. Peck

Alabama, April 1980, $\$ 22.50$

The Foundation and Structure

of Sartrean Ethics

By Thomas C. Anderson

Kansas, 1979, $\$ 14.00$

Histoire simple et vêritable

By Ghislaine Legendre

Montréal, 1979, \$19.95

Line in the Margin

Juan Ramón Jiménez and His Readings in Blake, Shelley, and Yeats

By Howard T. Young

Wisconsin, 1979, \$22.50

The Picaresque Hero in European Fiction By Richard Bjornson

Wisconsin, 1977, $\$ 6.95 \mathrm{p}$.

Treatise on Laughter

By Laurent Joubert

Translated and annotated

by Gregory de Rocher

Alabama, April 1980, $\$ 16.25$

SLAVIC AND EASTERN EUROPEAN LITERATURE AND LITERARY CRITICISM

The Old Man and the Bureaucrats

By Mircea Eliade

Notre Dame, March 1980, $\$ 8.95$

Soviet Satire of the Twenties

By Richard L. Chapple

Florida, May 1980 , tentatively $\$ 6.00$ 


\section{Books from University Presses}

OTHER LITERATURE AND LITERARY CRITICISM

The Cretan Glance

The World and Art of Nikos Kazantzakis

By Morton P. Levitt

Ohio State, April 1980, $\$ 12.50$

\section{A Knot in the Thread}

The Life and Work of Jacques Roumain

By Carolyn Fowler

Howard, March 1980, $\$ 12.95$

\section{Rilke}

The Alcbemy of Alienation

Edited by Frank Baron, Warren R. Maurer, and Ernst S. Dick

Kansas, April 1980, $\$ 18.00$

\section{Spenser Studies}

A Renaissance Poetry Annual, Volume I

Edited by Patrick Cullen and

Thomas P. Roche, Jr.

Pittsburgh, March 1980, \$14.95

\section{DRAMA, THEATRE, AND CINEMA}

\section{Damien}

By Aldyth Morris

Hawaii, February $1980, \$ 3.50$

Gold Diggers of 1933

(Wisconsin/Warner Bros. Screenplay Series)

Wisconsin, May 1980, \$4.95

To Have or Have Not

(Wisconsin/Warner Bros. Screenplay Series)

Wisconsin, May 1980, $\$ 4.95$

\section{To the Third Empire}

Ibsen's Early Drama

By Brian Johnston

Minnesota, February 1980, $\$ 20.00$

\section{FOLKLORE}

\section{Folklore from Kansas}

Customs, Beliefs, and Superstitions

By William E. Koch

Kansas, January 1980, $\$ 20.00$

\section{PHILOLOGY}

Classical Rhetoric and Its Christian and Secular Traditions from Ancient

to Modern Times

By George A. Kennedy

North Carolina, February 1980,

$\$ 18.00 \mathrm{cl}$., $\$ 9.00 \mathrm{p}$.

\section{POETRY}

Dear Blood

By Leonard Nathan

Pittsburgh, February 1980,

$\$ 9.95 \mathrm{cl}$., $\$ 4.50 \mathrm{p}$.

\section{Goldilocks in Later Life}

By R. M. Ryan

Louisiana State, March 1980

$\$ 9.95 \mathrm{cl}$., $\$ 4.95 \mathrm{p}$.

\section{The Need to Hold Still}

By Lisel Mueller

Louisiana State, March 1980,

$\$ 9.95 \mathrm{cl}$., \$4.95 p.

\section{Sovereign Sun}

By Odysseus Elytis

Translated by Kimon Friar

Temple, 1974, $\$ 10.00 \mathrm{cl}$; 1979, $\$ 7.95$ p.

\section{The Story They Told Us}

of Light

By Rodney Jones

Alabama, March 1980,

$\$ 8.75 \mathrm{cl}$., $\$ 5.95 \mathrm{p}$

\section{Sure Signs}

New and Selected Poems

By Ted Kooser

Pittsburgh, March 1980, $\$ 9.95$ cl., $\$ 4.50$ p.

\section{REFERENCE AND BIBLIOGRAPHY}

American and British Literature, 1945-1975

An Annotated Bibliograpby of

Contemporary Scholarsbip

By John L Somer and Barbara Eck Cooper

Kansas, February 1980, $\$ 17.50$

Catalog of Little Magazines

By Robert F. Roeming

Wisconsin, January 1980, $\$ 19.50$

\section{A Critical Bibliography of}

French Literature

Volume 6, The Twentieth Century, in 3 parts

Edited by Douglas W. Alden

and Richard A. Brooks

Syracuse, January $1980, \$ 120.00 / 3$ book set 


\section{"Iamnothing buta}

literary lizard, warming



Passionate, witty, analytical, and erotic, Flaubert's letters are a dazzling display of a writer's art and life.

They range from amorous, yet

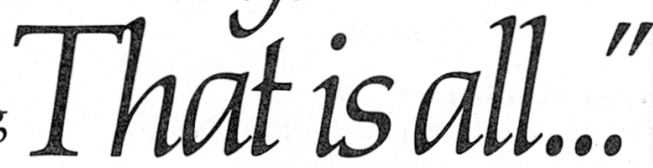
often sadistic, epistles to his beautiful mistress, to colorful accounts of his trips to the temples and brothels of the Mideast.

Most important, the letters chronicle one of the central events in literary history, the composition of Madame Bovary. And throughout this collection, Steegmuller provides a thoroughly satisfying critical and historical text.

It is, as Leon Edel says, "An enchanting book. Once one starts reading....it's difficult to put down." $\$ 12.50$ illustrated.



Selected, Edited, and Translated by Francis Steegmuller The Belknap Press of

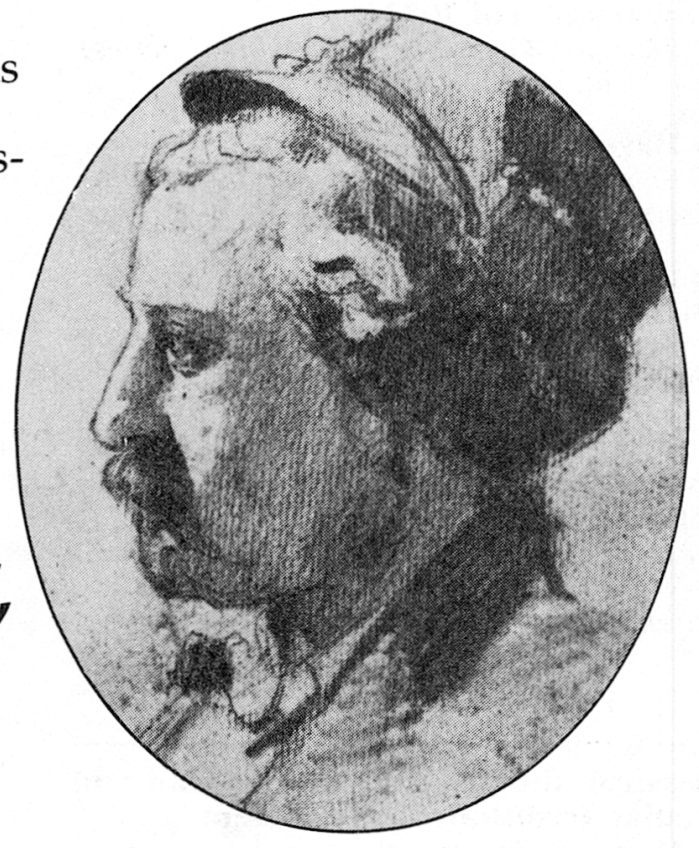

Courtesy M. Jean Ducourneau and Dr. B. Jean.

Harvard University Press Cambridge, Massachusetts 02138 


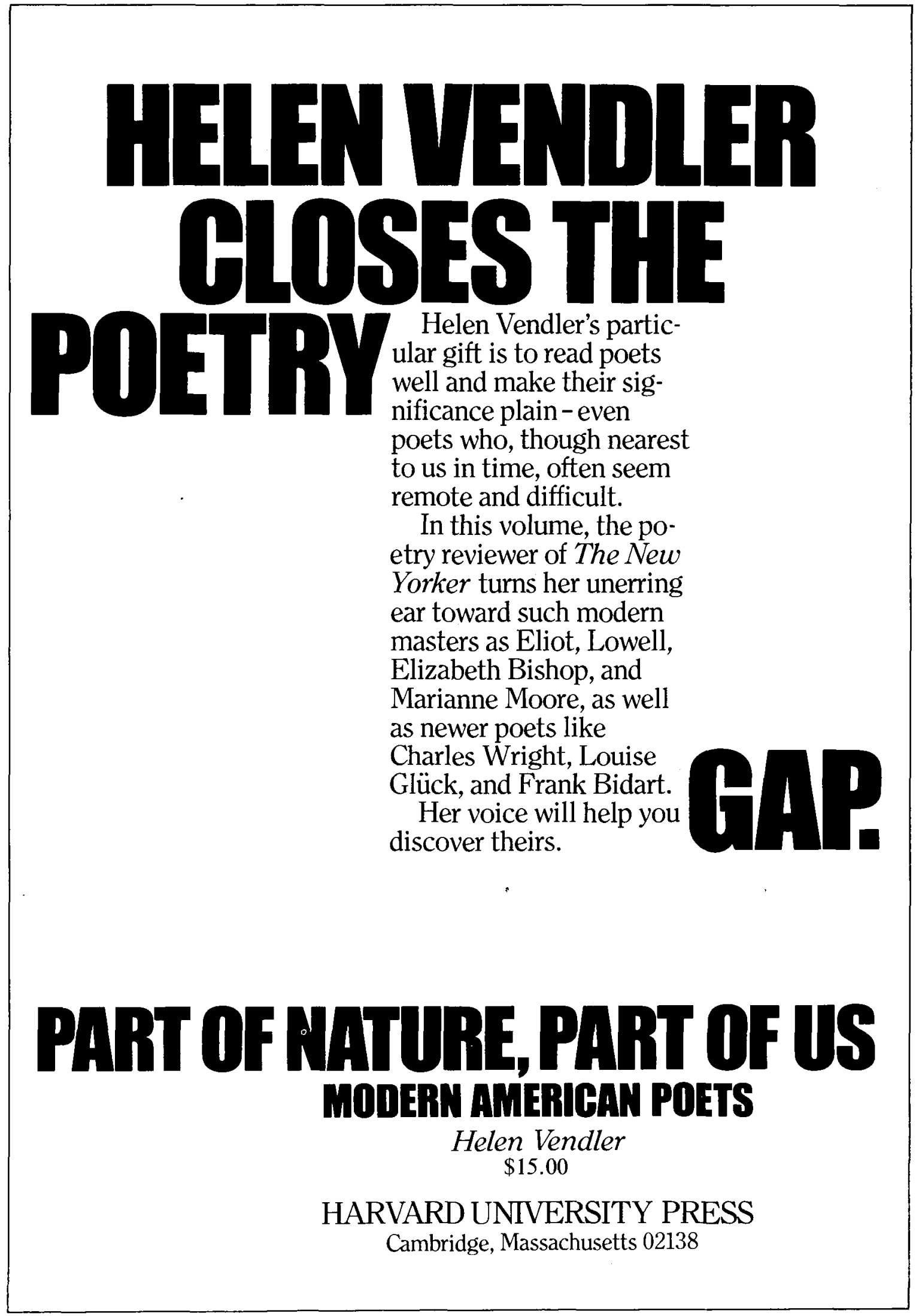




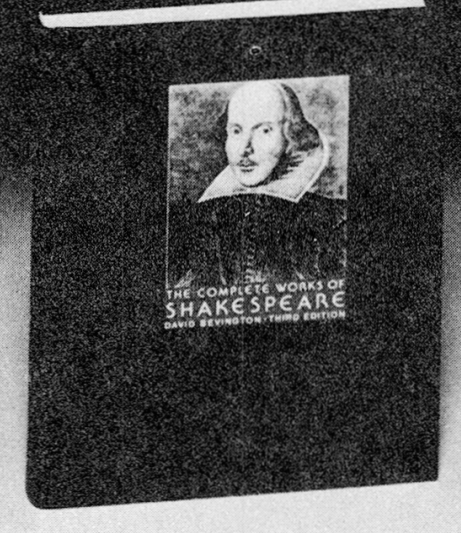

\section{The Complete Works of Shakespeare Third Edition}

David Bevington, The University of Chicago

The teaching Shakespeare is tailored even more closely than previous editions to your classroom needs.

- Completely reedited play texts-now arranged chronologically within genres

- Single editorship to provide unequaled continuity and consistency

- Editorial Advisory Board of $\mathbf{4 5}$ well-known Shakespearean scholars

- New and accessible page design

- Speech prefixes spelled out for easy. reading

- Full stage directions to assist in visualizing action onstage

- Glosses signaled by line numbers and positioned at the foot of the appropriate column

- Handsome illustration program

Available now, 1760 pages, hardbound

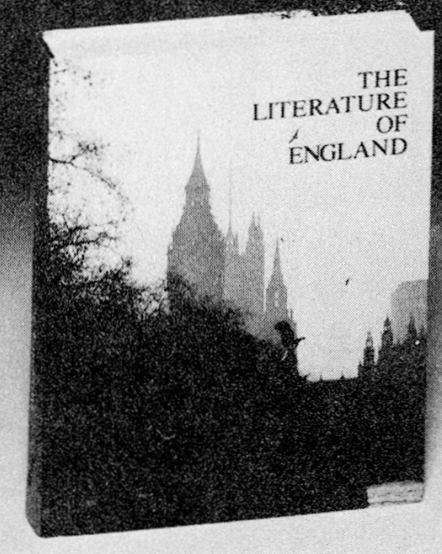

\section{The Literature of England Third Edition}

George K. Anderson, Emeritus,

Brown University/William E. Buckler, New York University/Mary Harris Veeder, Indiana University, Northwest

Setting new standards for readability and teachability, with...

- Manageable size and length

- Over 600 balanced and critically significant selections, chosen on the basis of hundreds of teacher surveys

- Interesting and readable introductions which provide the social and historical background for each major period

- Revised headnotes and explanatory footnotes

- Complete new illustration program

- Glossary of literary terms

Available now, Single-volume hardbound edition, 1263 pages; Two-volume softbound edition 622 and 634 pages respectively

\section{Scott, Foresman and Company}



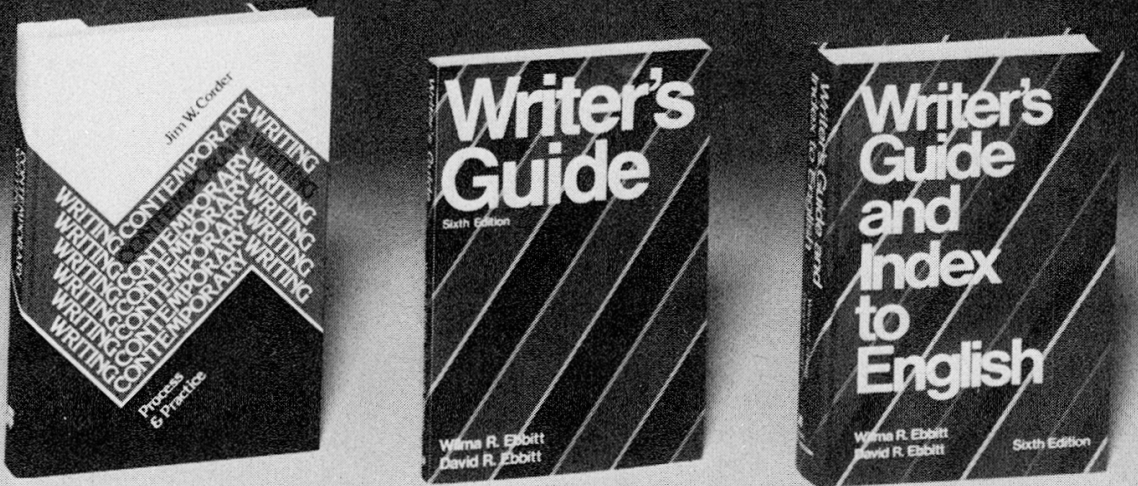

\section{Writing Research Papers}

\section{A Complete Guide Third Edition}

James D. Lester, Austin Peay State University

The Third Edition of the most successful and best-selling research paper manual now recommends the MLA format for endnotes, long quotes, and the bibliography. Increased coverage of the most common problems facing beginning researchers enables them to write with skill, ease, and authority. Features include a new sample research paper and note cards, an updated list of reference works, and additional footnote and bibliography entries. March 1980, 196 pages, softbound, with Instructor's Manual

\section{Contemporary Writing \\ Process and Practice}

Jim W. Corder, Texas Christian University

Readable, practical, complete, and authoritative, Contemporary Writing is the perfect blend of traditional and contemporary rhetorical wisdom, presenting techniques for generating and developing subjects, for building relationships with an audience, and for structuring and refining their written work. Available now, 493 pages, hardbound, with Instructor's Manual

\section{Writer's Guide Sixth Edition}

Wilma R. Ebbitt, T he Pennsylvania State University/David R. Ebbitt

A complete rhetoric and composition guidebook, Writer's Guide, Sixth Edition, is packed with the kind of practical instruction and realistic advice that helps student writers develop confidence and competence.

Available now, 400 pages, softbound, with Teacher's Guide

\section{Writer's Guide and Index to English Sixth Edition}

Wilma R. Ebbitt, The Pennsylvania State University/David R. Ebbitt

A truly modern, comprehensive rhetoric and handbook for today's students.

Available now, 715 pages, hardbound, with Teacher's Guide

For further information write Jennifer Toms, Department SA 1900 East Lake Avenue Glenview, Illinois 60025 



Second Edition

General Editor: GEORGE McMICHAEL, California State University, Hayward Advisory Editors: Frederick Crews, J. C. Levenson, Leo Marx and David E. Smith paperback 1980

Volume I: COLONIAL THROUGH ROMANTIC Volume II: REALISM TO THE PRESENT

The Second Edition of the leading anthology of American literature is even more inclusive than its predecessor.

It features a new $6 \times 9$ format-the pages now are easier to read and provide more margin for writing; the volumes are thinner and easier to carry, and the bindings are more durable.

Anthology of American Literature, Second Edition offers:

- All the full-length works of the first edition as well as these additional works in their entirety: Cooper's The Prairie, Chopin's The Awakening, Roth's Goodbye Columbus

- All the plays of the first edition as well as these additional plays in their entirety: Tyler's The Contrast, Williams's The Glass Menagerie
- Almost all the short works of the first edition and important new ones: Longstreet's The Fight, Thorpe's The Big Bear of Arkansas, Harris's The Snake-Bit Irishman, Freeman's A New England Nun, Jewett's A White Heron, Cable's Belles Demoiselles Planation, Bierce's An Occurrence at Owl Creek Bridge, Lardner's Some Like Them Cold, Wolfe's Only the Dead Know Brooklyn and The Far and the Near, Thurber's The Secret Life of Walter Mitty, Oates's How I Contemplated the World from the Detroit House of Correction and Began My Life Over Againand others.

- Almost all the poetry of the first edition as well as substantial additions-especially to the works of Dickinson, Frost, and Cummings. Also, the new inclusion of works by Berryman and Ammons.

\section{Macmillan Publishing Co., Inc.}




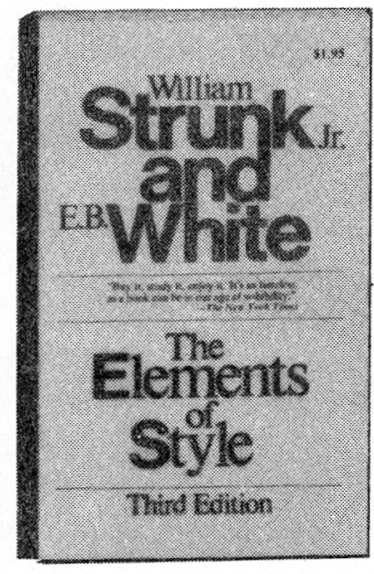

\section{The perennial bestselling classic, now available in a new revised edition...}

\section{THE ELEMENTS OF STYLE ${ }_{\text {thrd Eatiton }}$}

\section{WILLIAM STRUNK JR. \& E. B. WHITE}

bardcover/paperback 1979

For professional writers, college and high school students, and business executivesanyone interested in improving writing skills... an ideal supplement for any course in English departments... The San Francisco Chronicle calls it the "book everyone who deals in English words should go right out and buy today."
- "It's as timeless as a book can be."

-The New York Times

- "One of the best books on the fundamentals of writing..."

- The Boston Globe

- "Distinguished by brevity, clarity, and good sense..." - The New Yorker

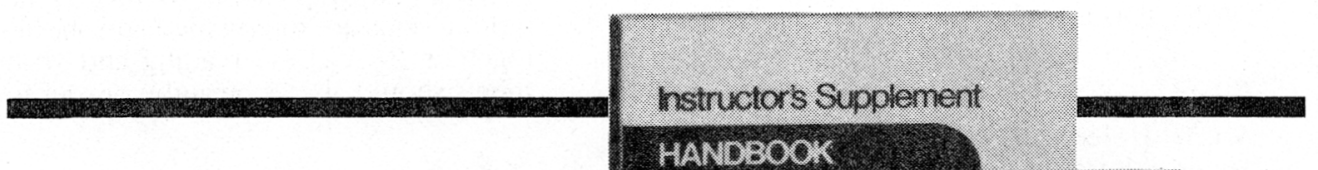

\section{HANDBOOK}

DONALD W. GOOD \& THOMAS L. MINNICK, both, Ohio State University 1979

This is a concise handbook-rhetoric priced at $\$ 7.95$; it introduces the whole essay, the paragraph, the sentence, and the word directly and coherently provides a comprehensive guide to usage includes numerous examples from professional essayists, students, and the authors $\bullet$ presents a detailed analysis of a complete essay and no fewer than seven model essays from 500 to 2,500 words long. An INSTRUCTOR'S MANUAL including diagnostic tests and a STUDENT WORKBOOK are available.

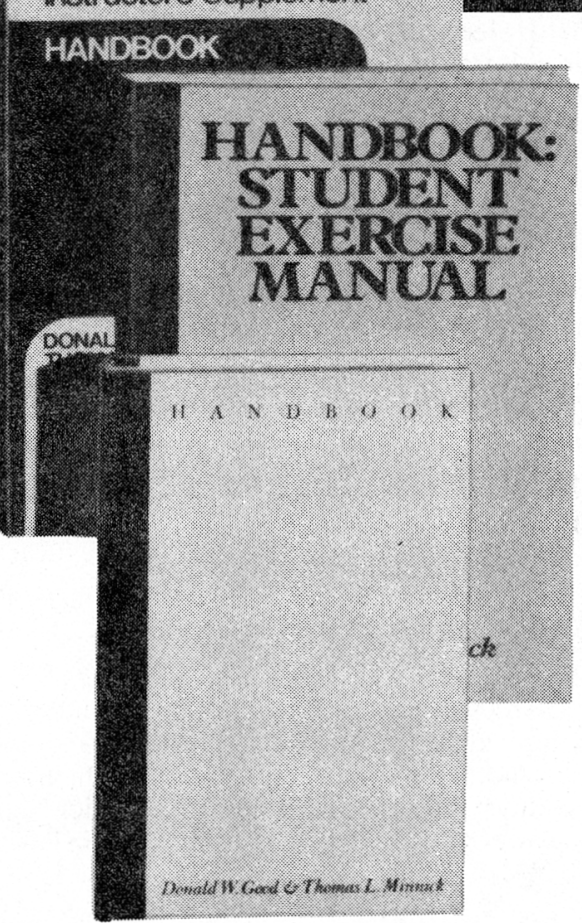

\section{Macmillan Publishing Co., Inc.}

866 THIRD AVENUE, NEW YORK, NY 10022 


\section{Anthologies and Readers}

\section{Masterpieces of the Drama \\ Fourtb Edition}

ALEXANDER W. ALLISON, University of Michigan; ARTHUR J. CARR, Williams College; ARTHUR M EASTMAN, Virginia Polytechnic Institute and State University

paperback 1979

29 plays, from those of the ancient Greeks to the present day. The text is annotated, and the editors provide a general ESSAY ON DRAMA as well as INTRODUCTIONS to all plays

\section{New}

\section{Introduction to Literature: Stories \\ Third Edtion}

LYNN ALTENBERND, University of Illinois; \& LESLIE L. LEWIS

paperback 1980

This anthology of short stories features $A$ Handbook for the Study of Fiction, an in-depth guide to perceptive reading. Of the 45 short stories included here, 41 are new to this edition. An INSTRUCTOR'S MANUAL is available.

Fiction 100:

An Anthology of Short Stories

Second Edition

JAMES H. PICKERING

paperback 1978

Still the leading text in the field.

Includes Saul Bellow, Arthur Conan Doyle, Harlan Ellison, F. Scott Fitzgerald, Carson McCullers, Eudora Welty; Donald Barthelme, Dashiell Hammett, Shirler Jackson, D. H. Lawrence, Dorothy Parker, E. B. White-plus many more. An INSTRUCTOR S MANUAL is available.

\section{Reading for Rhetoric Applications for Writing, Fourtb Edition}

CAROLINE SHRODES, CLIFFORD A. JOSEPHSON, JAMES R. WLSON

\section{paperback 1979}

Sixty essays ( 47 new to this edition!) are incorporated into eight categories of rhetorical method identification, definition, classification, comparison and contrast, illustration, analysis, argument and persuasion, and diction and tone. An INSTRUCTOR'S MANUAL is available.

\section{Macmillan Publisbing Co., Inc.} 866 THIRD AVENUE, NEW YORK, NY 10022

\section{The Conscious Reader}

Second Edition

CAROLINE SHRODES,

HARRY FINESTONE,

MICHAEL SHUGRUE,

paperback 1978

Selections by Jack London, Woody Allen, Norman

Mailer, Carolyn Heilbrun, Betty Roszak, Nathaniel

Hawthorne, Pauline Kael, Katherine Ann Porter, Ray Bradbury; Thomas S. Szasz, Marshall McLuhanplus many more. An INSTRUCTOR'S MANUAL is available.

\section{Composition}

New

\section{Comprehension and Composition}

\section{An Introduction to the Essay}

ANN B. DOBIE \& ANDREW J. HIRT, both, University of Southwestern Louisiana paperback 1980

This rhetoric/reader/handbook for basic composition features 128 graded essays.

The book's philosophy is this: 1) Reading and writing skills are intertwined and should be taught together. 2) A class's reading and writing assignments should always be at the proper level.

\section{New \\ English Fundamentals Seventb Edition-Form A}

DONALD W. EMERY, University of Washington JOHN M. KIERZEK, Oregon State University; PETER LINDBLOM, Miami-Dade Community College paperback 1980

Still thorough, still detailed, and still stressing grammatical precision, the new edition of this text/ workbook emphasizes the sentence as a wholewith greater attention given to sentence building and combining.

\section{Handbook of English Fundamentals}

DONALD W. EMERY, University of Washington; JOHN M. KIERZEK, Oregon State University; PETER LINDBLOM, Miami-Dade Community College paperback 1978

By the authors of the highly successful English Fundamentals, this brief but complete handbook of grammar prescribes good, correct writing for all purposes. It begins with punctuation, mechanics, capitalization, and spelling, and progresses to sentence structure and word choice, and ends with paragraphs, essays, and research papers. 
New

\section{Paragraph Practice}

Writing the Paragraph and the Short Composition, Fourth Edition

KATHLEEN E. SULLIVAN, Merritt College paperback 1980

This text/workbook shows students that the rules of effective writing are common-sense principles. It also features model paragraphs for students to imitate. Among the changes in this new version: expanded material on the short composition.

\section{The Vital Arts-}

\section{Reading and Writing}

DOROTHY RUBIN, Trenton State College

\section{paperback 1979}

This unique text-workbook covers all writing elements from the sentence to the short theme in a novel sequence of interwoven lessons. Students master simple principles without monotony: Reading skills are treated simultaneously with writing. Each lesson is accompanied by numerous selfpacing exercises that encourage overlearning. Diagnostic tests, puzzles, and word games are also included. An INSTRUCTOR S MANUAL is available.

New

\section{Writing:}

\section{Analysis and Application}

A Rhetoric, Reader, and Handbook

ROBERT F WLLSON JR

paperback $\quad 1980$

This beginning composition text stresses writing that is colorful and interesting as well as correct. It concentrates on the careful reading of prose as a means to writing improvement. It offers a wide range of essays related to the task of writing; and it includes the complete "Handbook of Writing and Revision" of 7 be Macmillan Handbook of English, Gth ed

\section{Technical Writing}

\section{Technical Writing}

\section{Principles and Forms}

DEBORAH C. ANDREWS, Drexel University;

MARGARET B. BLICKLE, The Ohio State University paperback 1978

This comprehensive textbook-manual covers all important forms into which technical and scientific information must be placed and integrates this coverage with rhetorical theory. The book is aimed at "real-life" situations and is based on rears of consulting experience in government, inclustry, and research. Examples are drawn from publications in engineering, architecture, natural resources, biology; agriculture, hone economics, physics, chemistry; medicine, library science, and marine technol(g): An INSTRUCTOR'S MANUAL is available
Vocabulary

\section{Gaining Word Power}

DOROTHY RUBIN, Trenton State College

paperback? 1978

This vocabulary improvement text-workbook concentrates on combining forms as a unit.

The organization is self-pacing and includes overlearning as an essential reinforcement of instruction. There are numerous exercises involving words in context, matching pairs, true-false, analogies, crossword puzzles, and word scrambles. An INSTRUCTOR'S MANUAL, is available.

\section{Developmental Reading.}

\section{Reading and Learning}

\section{Power}

DOROTHY RUBIN, Trenton State College

\section{paperback 1980}

This self-pacing text/workbook teaches learning skills as well as reading, vocabulary, and word analysis skills.

It utilizes the principles of self-pacing, knowl edge of results, distribution of practice, and overlearning: it was designed to be stimulating and fun for students with many enjoyable word games, rid dles, puzzles, etc.

\section{The Art of Efficient Reading}

\section{Third Edition}

GEORGE D. SPACHE, Spache Educational Consultants, Inc.; PAUL CONRAD BERG, University of South Carolina

paperback 1978

This widely used developmental reading manual encourages students to learn new reading habits and improve speed and comprehension with a minimum of assistance from the instructor. The new edition has additional reading exercises throughout and applies an adaptation of the CLOZE Method to increase reading speed and comprehension.

\section{Secretarial Reference}

Neu'

\section{Revised Standard Reference for Secretaries and Administrators}

MARGARET H. THOMPSON \& J. HAROLD JANIS

paperback: 1980

A revision of the Nen' Stanclard Reference for Secrelaries and Administrative Assistants; it covers English usage, punctuation, etc. as well as office procedures and business-related facts and figures.

Macmillan Publisbing Co., Inc. 866 THIRD AVENUE, NEW YORK, NY 10022 


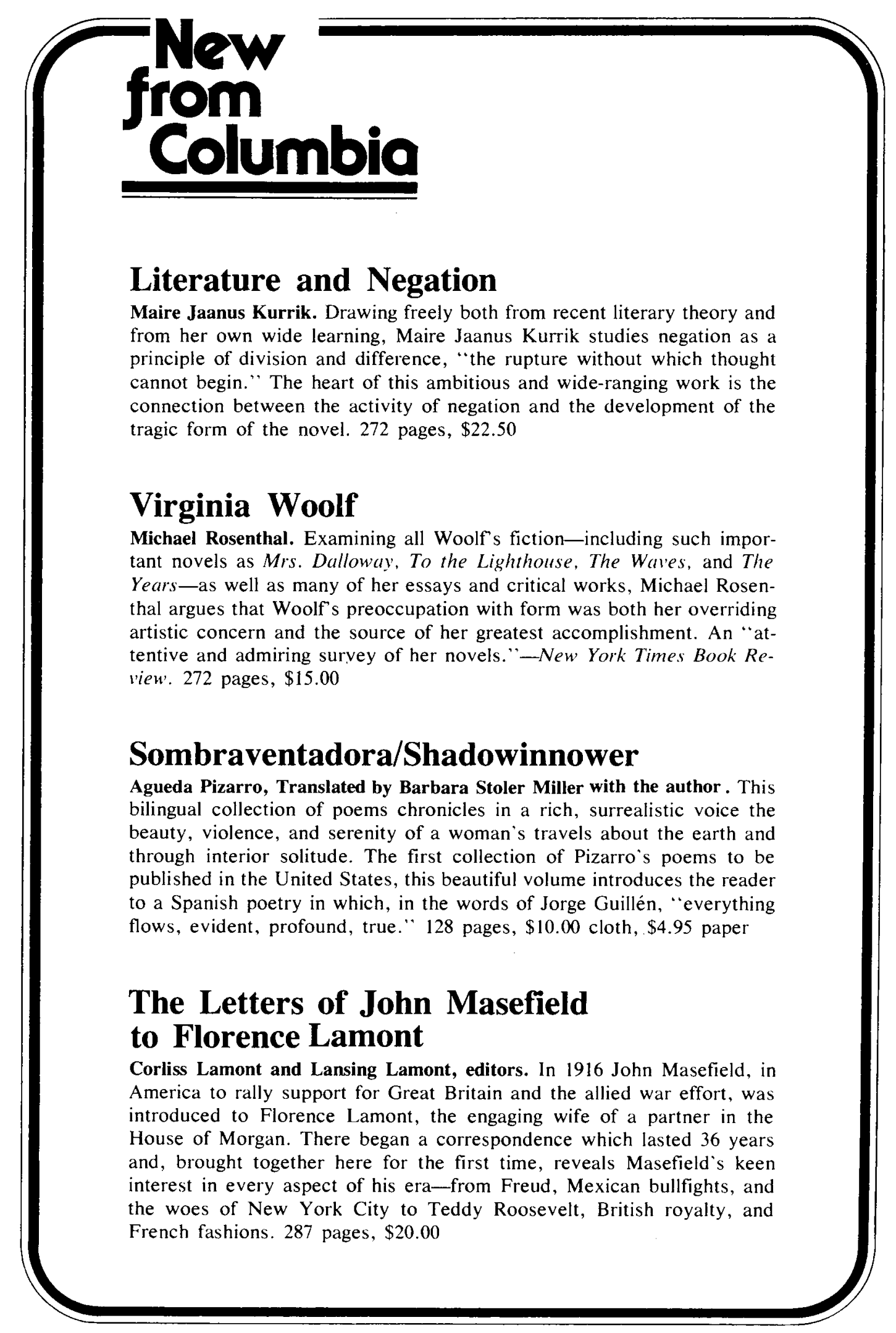




\section{The Abbey, Ireland's National Theater}

Hugh Hunt. Based in part on minute books and other classified documents in the theater's archives, this first authorized history of the Abbey Theater in over 25 years provides a unique chronicle of the renowned institution's tempestuous growth, along with first-hand portraits of the Abbey's founders and contributors, including W. B. Yeats, Lady Gregory, J.M. Synge, and "A.E." (George Russell). 306 pages, illus., \$18.95

\section{Twentieth-Century Russian Drama}

From Gorky to the Present

Harold B. Segel. This first survey in English of Russian drama after Chekhov covers every aspect of Russian drama in this century, including the work of Andreev, Bely, Blok, Sologub, Mayakovsky, Tsvetaeva, Olesha, Solzhenitsyn, and many others. "This book is essential for any drama or Russian literature collection." Library Journal. 502 pages, illus., $\$ 27.50$ cloth, $\$ 12.00$ paper

\section{Modern Japanese Drama An Anthology}

Ted T. Takaya. "Little modern Japanese drama has been translated, so this book is a breakthrough. Five very contemporary plays are presented ... ranging from Mishima's modern Nō form, through Yashiro's realistic and earthy biography, to Betsuyaku's near-absurd portrayal of human existence." Library Journal. 424 pages, illus., $\$ 17.50$

\section{Metafictional Characters in Modern Drama}

June Schlueter. "Schlueter chronologically examines the theme of double exposure and double consciousness in Pirandello, Genet, Beckett, Weiss, Albée, Stoppard, and Handke. Her book is so well prepared that it is a pleasure to swallow. The author, to use theater talk, "does nice work.' " Library Journal. 143 pages, $\$ 15.00$

Now in paperback:

\section{Modern Hungarian Poetry}

Miklós Vajda, editor. Presenting the finest works by writers active in the postwar period, this volume at last makes a complete selection of modern Hungarian poetry available in English. With translations contributed by such leading American, British, and Canadian poets as Donald Davie, Robert Graves, Ted Hughes, and Richard Wilbur, Modern Hungarian Poetry provides "a pungent record of the human spirit in our time."Hudson Review 286 pages, illus., \$6.95

To order send check or money order to Dept. JN at the address below, including $\$ 1.30$ per order for postage and handling.

\section{COLUMBIA UNIVERSTTY PRESS}




\section{RANDOM HOUSE NOW SPEAKS your languaGe!}

For over fifty years, people have looked to Random House as the publisher of great literature; and for the past twenty, as a major source of fine college texts in many disciplines. Now, we have applied that accumulated store of literary and scholarly expertise to the expansion of our foreign language list. This year, we take great pride in introducing to you new selections of carefully planned and developed titles in Spanish, German, and Italian, as well as a new edition of one of the most popular and respected beginning German texts.

Over the next five years, we will continue to build on this effort, bringing you texts for complete college-level programs, in introductory and intermediate Spanish, German, French, and Italian. We want you to look to Random House as the source for all your foreign-language teaching needs.
Italian

PREGO! AN INVITATION TO ITALIAN

Graziana Lazzarino, University of Colorado, with Antonella Pease, University of Texas at Austin; Annamaria Kelly, University of Arizona; and Luigi Romeo, University of Colorado

Written by an all-italian team and monitored closely by a panel of over 40 coordinators of first-year courses nationwide, PREGO is a beginning text featuring an innovative communicative focus with a proven traditional approach to grammar. The text combines a thorough introduction to grammar with conversation, cultural information humor, and entertaining creative activities. PRECO is a complete program featuring the basic text, a lab manual, a written workbook, and a communications supplement.

Random House/March 1980/544 pages hardbound/Order Codes: 32376 (Text), 32537 (I.M.), 32538 (Workbook), 32539 (Lab Manual), 32540 (Activity Manual), 32541 (Tape Program), 32542 (Tape Transcripts) 


\section{WRITING SKILLFUL SENTENCES}

Philip Eggers, Manhattan Community College

This important new sentence grammar features the compactness and reference apparatus of a standard handbook together with the concentrated focus of a workbook to help students overcome basic writing problems. In a positive and sensitive tone, it helps students increase their grasp of standard written English through composing activities, self-help drills, and proofreading practice.

Random House/December 1979/288 pages paperbound/Order Codes: 32390, 32470 (I.M.)

\section{PLAIN ENGLISH PLEASE: A Rhetoric Fourth Edition}

Gregory Cowan and Elizabeth McPherson, Forest Park Community College

This step-by-step composition text takes informal, non-technical approaches to developing clear and effective papers. The fourth edition has improved explanations of definition, comparison, and logic; many new, updated examples and exercises; a new chapter on the term paper; greater coverage of business letters; and expanded coverage of "The Longer Paper" (appendix III) that includes an annotated sample research paper.

Random House/November 1979/490 pages paperbound/Order Codes: 32367,32471 (I.M.)

\section{READING AND WRITING SHORT ESSAYS}

Morton A. Miller, University of Hartford

Seventy-seven brief and rarely anthologized essays, over $50 \%$ of them complete works, by such writers as Jack London, Virginia Woolf, Richard Wright, Somerset Maugham, Dorothy Parker, Anais Nin, and Ralph Ellison-fully introduced and annotated-provide superb models for your students' own essay-writing. Random House//anuary 1980/416 pages paperbound/Order Codes: 32214,32468 (I.M.)

\section{THE BORZOI COLLEGE READER} Fourth Edition

Charles Muscatine, University of California at Berkeley, and Marlene Griffith, Laney College

All selections in this classic reader - whether by George Orwell or Dorothy Sayers, Walter Lippmann or Joan Didion-expose students to fresh ideas, attitudes, and assumptions, both classical and contemporary. In the new edition, more selections from pre-20th century authors are balanced by new sections on topics of current interest, including work, America as others see us, education, media and mass culture, and the searctr for identity.

Alfred A. Knopf/March 1980/672 pages paperbound/Order Codes: 32419, 32467 (I.M.)

\section{THINKING IN WRITING:}

\section{Structures for Composition}

Donald McQuade, Queens College, City University of New York, and Robert Atwan

An outstanding antholøgy of classic and contemporary writing that clearly illustrates rhetorical strategies while, at the same time, showing the realities of thinking and the composing process.

Alfred A. Knopf/March 1980/476 pages paperbound/Order Codes: 32392, 32469 (I.M.)

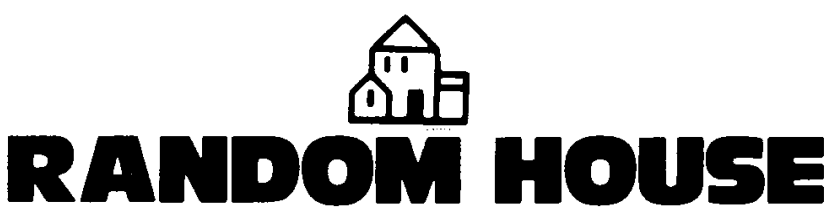

College Review Desk, 400 Hahn Road, Westminster, MD 21157 


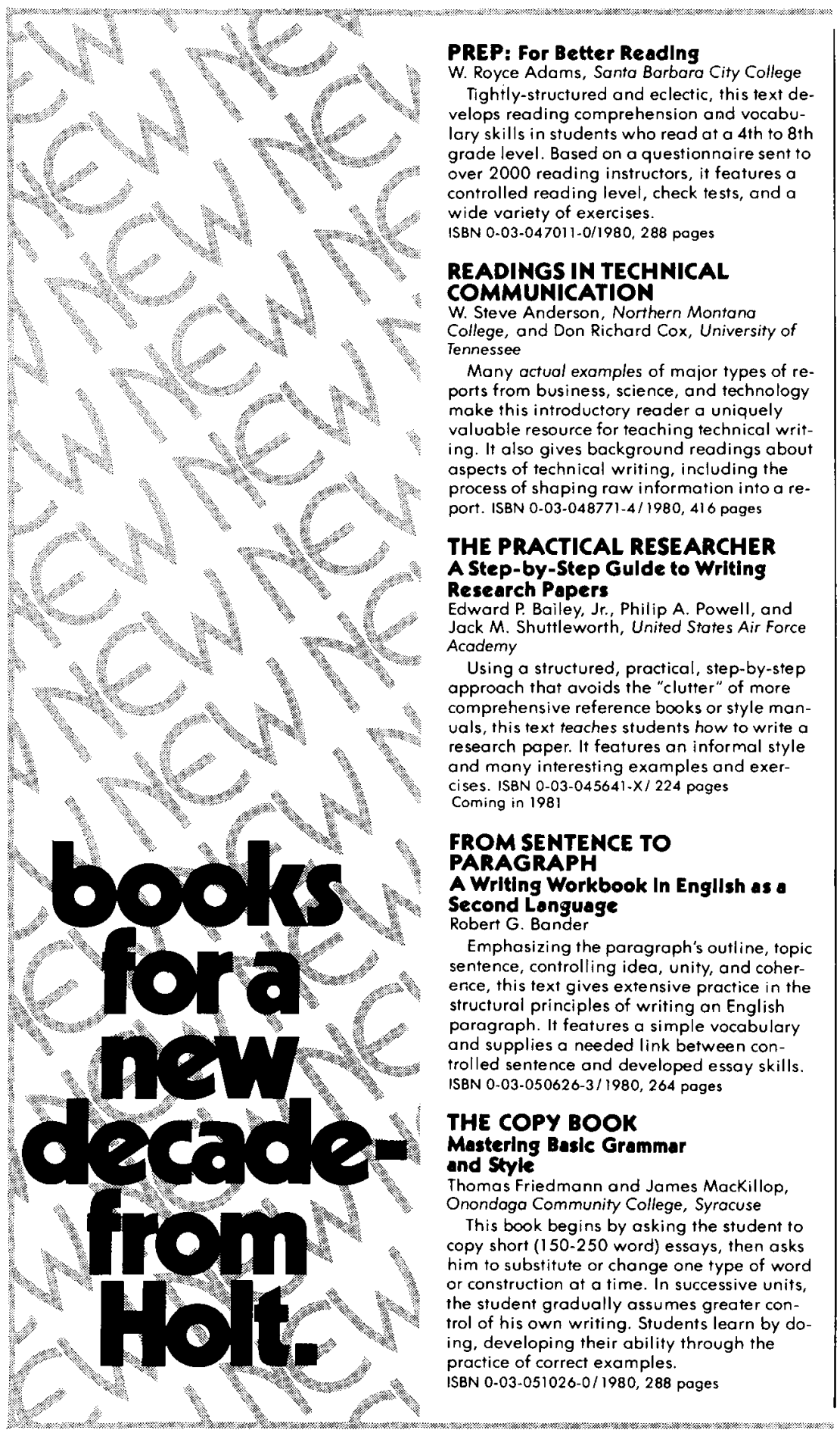




\section{A CONCISE GUIDE FOR WRITERS,} Fifth Editlon

Louis E. Glorfeld, University of Denver, Dovid A. Laverman, Canisius College, Buffalo, and Norman C. Stageberg, University of Northern lowo

Flexible, simple, and concise, this guidebook concentrates on 50 of the most frequen writing faults of college freshmen - but also gives advice on writing themes and on broader rhetorical problems. This new edition feotures revised sections on writing research papers and taking tests.

ISBN 0-03-048356-5/1980, 224 pages

\section{HANDBOOK FOR WRITERS} Grammar, Punctuation, Diction, Rhetorlc, Research

Celio Millword, Boston University

This new descriptive handbook does more than tell the student what is right and whot is wrong: it explains why English works the way it does. It is, therefore, both useful and interesting for students at all levels. ISBN 0-03-017796-0/1980, 512 pages

\section{WORKBOOK FOR WRITERS}

Linda Bowie

Brief explanations of the basics of grammar and rhetoric help students tackle a wide variety of exercises in this workbook. It follows the Handbook for Writers in orgonization, but may be used independently. Each chapter features a troubleshooting section that concentrates on the specific areas of greatest difficulty.

ISBN 0-03-040721-4/1980, 264 pages

\section{SUCCESSFUL READING}

Key to Our Dynamic Soclety

Third Edition

Maxwell $H$. Norman, assisted by Enid S. Kass Norman, MiroCosta College, Del Mar, California

By emphasizing techniques for sharpening study skills, this test/workbook for developmental reading helps students in the 25-75 percentiles become more effective readers. It gives exercises on vocabulary, comprehension, reading techniques and their applications, outlining, summarizing, and more Half the readings are new in this edition. ISBN 0-03-04962I-7/1980, 264 pages

\section{BREAKTHROUGH}

\section{From Reading to Writing}

John W. Presley, Augusta College, and

William M. Dodd, Augusta Youth Development Center

A workbook and reader for developmental English, with extensive work on essay organization, vocabulary, and reading com prehension. Controlled readings and informal, professional essays are followed by questions on vocabulary and reading comprehension as well as detailed writing assignments. ISBN 0-03-048776-8/1980, 336 pages

\section{FROM SIGHT TO INSIGHT}

Steps in the Writing Process

Jeff Rackham, Capital University, Columbus, Ohio

Each unit of this freshman composition text follows the natural steps of the writing process-subject, audience, form, first draft, rewriting, editing. Successive units lead students step by step from a personal, imaginative, and concrete approach towards objec-

tive, critical, and abstract writing

ISBN 0-03-047506-X/1980, 500 pages

\section{STUDIES IN THE SHORT STORY,}

\section{Fifth EdItion}

Virgil Scott, Emeritus, Michigan State

University, and David Madden, Louisiana State University

25 new stories bring the total from 44 to 54 in this widely-used short story anthology's new edition. A new section on authors' revisions, with two examples, shows students the creotive process. Also featured are more

modern and unconventional stories and more stories by women and minorities.

ISBN 0-03-043131-X/1980,636 pages

\section{BETTER WRITING}

\section{From Paragraph to Essay}

Gene Stanford, Utica College of Syracuse University, and Marie N. Smith

Paragraph development and organization, coherence, unity, essay organization, proofreading - this basic composition workbook breaks down all the basic skills of writing into small, logical steps. Its self-teaching, self-checking format allows students to move ahead at their own pace.

ISBN 0-03-051161-5/1980, 224 pages

\section{AN AMERICAN RHETORIC,}

\section{Fifth Edition}

William W. Watt, Emeritus, Lafayette College

This completely redesigned edition adds a section on prewriting and a glossary of grammatical and rhetorical terms. But it re tains its lively style, many examples and exercises, and emphasis on good as well as correct writing, thereby reflecting the author's philosophy that a guide to good writing should itself be well written.

ISBN 0.03-044166-8/1980, 480 pages

For complimentary copies, please send course title and approximate enrollment to:

JAMES M. RYDER

HOLT, RINEHART AND WINSTON

383 MADISON AVENUE NEW YORK, NY 10017 


\section{Lionel Trilling}

CRITICISM AND POLITICS

\section{William M. Chace}

For fifty years Lionel Trilling was a major critical presence in America. "He believed passionately," wrote Irving Howe, "and taught a whole generation also to believe, in the power of literature-its power to transform, elevate, and damage." In this first comprehensive study of Trilling's criticism and fiction, Professor Chace demonstrates the range of Trilling's influence and examines his part in America's search for a sense of its cultural self. "Reading Chace is rather like reading Trilling's essays for the first time: one experiences the same sense of a sinuous, resourceful mind at work upon concerns which are as central to our age as they are delicate, elusive, and resistant to simple formulation." Thomas Flanagan. "A fine study, lucid and gracefully written, of one of the two or three critics in mid-century America that mattered the most."-M. H. Abrams. $\$ 12.95$

\section{Stanford University Press}

\section{An Introduction to Old Irish R. P. M. and W. P. Lehmann}

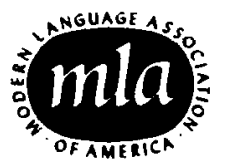

Written by two distinguished linguists, this important new book enables the reader to learn the Old Irish language while studying its literature. The basic text consists of a notable Old Irish story supplemented with poems, glosses, and annotations. The grammatical information in the annotations is summarized in separate sections dealing with specific syntactical constructions and forms. The book includes a glossary, facsimiles of Old Irish manuscripts, and discussions of word formation, pronunciation, metrics, and other subjects necessary for a full appreciation of Old Irish, its literature, and the culture that produced it. Clothbound, 1975. 201 pp. $\$ 13.50$.

Send your order and check to:

\section{MLA Publications Center \\ 62 Fifth Avenue New York 10011}




\section{THE COMPLETE COLLEGE DICTIONARY THAT GIVES YOUR STUDENTS MORE OF EVERYTHING}

\section{Webster's New World Dictionary, 2nd College Edition 1980 Copyright}

\section{NEW COPYRIGHT!}

The 1980 copyright of Webster's New World Dictionary, 2nd College Edition (in either an adoption, plain, or indexed version) will be widely recognized as the most up-to-date college dictionary available. It contains hundreds of new words, new meanings for existing words, and other up-dated entries.

\section{NEW WORDS!}

Aerobics, anorexia nervosa, bok choy, broker (as a verb), CAT-scan, gasohol, Keogh plan, meltdown, the pits, ripple effect, sunset law, vested, wild card, and more.

\section{NEW MEANINGS!}

Flake, breather, magnetometer, and many others.

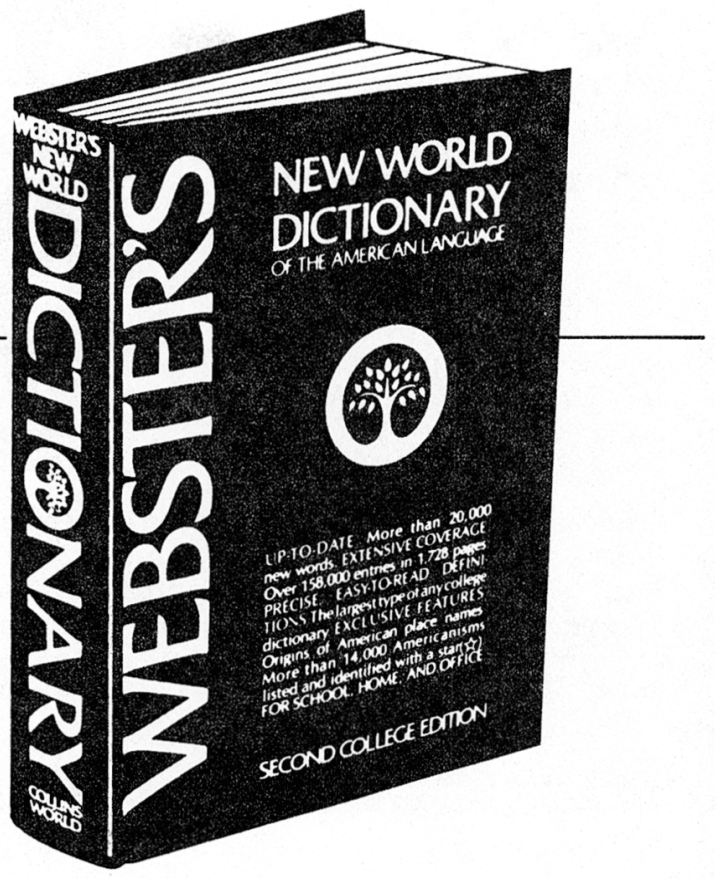

\section{NEW DATA!}

Current information on college, biographies, monetary units, and periodic table of chemicals.

\section{EASY TO USE!}

Lists everything in a single alphabetical order, including biographical and geographical names, foreign words, and abbreviations. Clear, simple sentences explain and define words, especially abstract nouns. Currerit spelling and syllabification is revealed along with newly accepted combined forms.

\section{EXTRA BONUSES!}

* Noted for its helpful system of usage notes, extensive synonymies, and outstanding etymologies that college students and linguists can use to trace origins of words and clarify meanings. Includes more etymologies than any other comparable dictionary.

* The only college dictionary that identifies over 14,000 thoroughly explained Americanisms, and uniquely shows the origins of American place names-cities, states, rivers, etc.

* Supplies geographical and biographical information-recent census data for major cities, new countries, and current positions of political leaders.

* The only complete college dictionary available in softcover version.

AND, WEBSTER'S NEW WORLD DICTIONARY has been adopted by the New York Times, United Press International, The Associated Press, and hundreds of other leading news media, as their primary authority on meaning and spelling. Also selected by the Library of Congress and the American Printing House for the Blind as the first and only college dictionary to be published in Braille.

ALSO, A FREE STUDY GUIDE is available to faculty for classroom use to help students learn dictionary skills and acquaint them with the features it contains-making your job easier. A Teacher's Edition of the Study Guide is available upon adoption.

1980

$1,692 \mathrm{pp}$.
Webster's New World Dictionary of the American Language, Second Editon, is published by William Collins Publishers, Inc., and is distributed to colleges and universities by Prentice-Hall, Inc.

For further information, or to order or reserve examination copies, please write: Robert Jordan, Dept. J-583, Prentice-Hall, Inc., Englewood Cliffs, NJ 07632.

For "SUPER-QUICK" service, dial TOLL FREE (800) 526-0485*, between 9:00 a.m. $-4: 30$ p.m. EST. Mon.-Fri.

"not applicable in New Jersey, Alaska, Hawaii or Puerto Rico. 


\title{
New publications in Literature
}

\section{Brilk and}

\section{Mayalkovsky}

by

\section{Vahan D. Barooshian}

Slavistic Printings and

Reprintings, Vol. 301

1979, XII + 158 pp. Pb.

DM 48.00 / US\$ 30.00

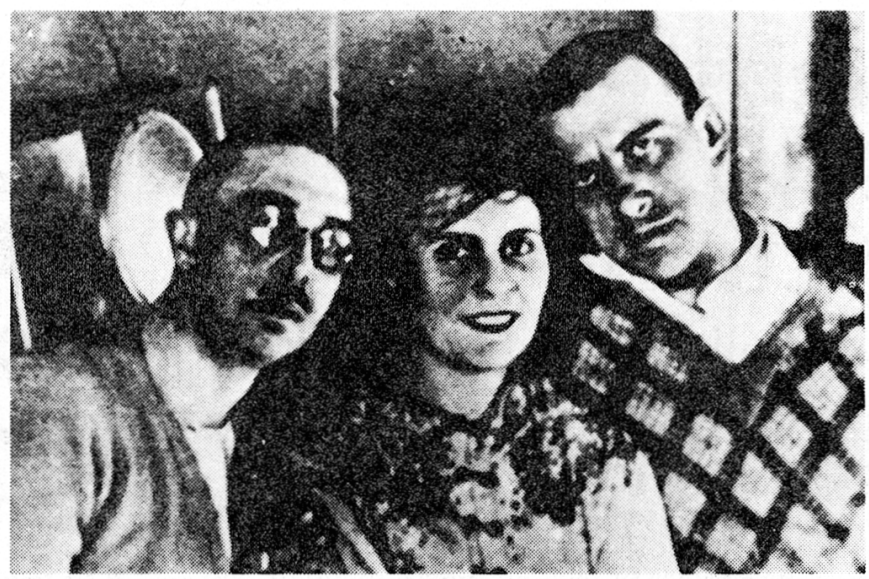

Osip Maksimovich Brik was one of the most elusive, mysterious and legendary figures in the history of Russian 20th-century literature. The recent death of his wife, Lilya Brik, has once again focused attention on the creative triangular relationship which they shared with the Soviet poet, Vladimir V. Mayakovsky. The story of that relationship, the Briks' efforts to find a place for Mayakovsky in the history of Soviet literature, and the ironic fate of the Briks in the Soviet Union today are treated extensively in this study.

\section{Donald Raymond Hilitchcock}

\section{The Appeal of Adam to Lazarus in Hell}

Slavistic Printings and Reprintings, Vol. 302

$1979, \mathrm{VI}+266$ pp. Cloth DM 80.00 / US\$ 50.00

The only known original East Slavic apocrypha - one of the most important works of Old Russian literatureis presented in this critical edition. This volume gives the original text, with an English translation, together with a detailed linguistic study and study of the literary sources.

\section{Marc Eli Blanchard}

\author{
Description: Sign, Self, Desire \\ Approaches to Semiotics, Vol. 43 \\ 1980, VIII + 300 pp. Cloth Approx. DM 72.00 / US\$ 45.00
}

A wide-ranging survey of the linguistic, philosophical and psychoanalytical implications of the development of a science of signs, based on the premises of Peirce, de Sassure and others. It both discusses general semiotic premises and investigates specific applications to literary texts, combining a solid knowledge of linguistics and, more generally speaking, of structural methods, with a good background in philology and literary scholarship.

Please send orders to your regular bookseller or directly to

for USA and Canada: Mouton Publishers, 200 Saw Mill River Road, HAWTHORNE NY 10532

for all other countries: Walter de Gruyter \& Co., P.O. Box 110240, D-1000 BERLIN-11

Prices are subject to change without prior notice.

\section{mouton publishers}

The Hague · Paris · New York 


\section{AUSGABEN DEUTSCHER LITERATUR des XV. bis XVIII. Jahrhunderts}

\section{Wolfgang Caspar Printz Ausgewählte Werke}

3 volumes

Volume 2: Satirische Schriften und historische Beschreibung der edelen

Sing- und Kling-Kunst

Edited by Helmut K. Krause

Octavo. IV, 527 pages. 1979.

Cloth DM 298,- ISBN 3110038609

The volume contains the satirical novel „Güldner Hund“, polemical pamphlets

directed at Johann Beer, and Printz' history of music from the year 1690.

\section{Wolfhart Spangenberg Sämtliche Werke}

In cooperation with Andor Tarnai edited by András Vizkelety

Volume 7: Dramenübersetzungen edited by Andor Tarnai

Octavo. IV, 633 pages. 1979.

Cloth DM 364,- ISBN 3110079372

Early 17 th century German adaptations of dramas by Euripides, Sophocles and Plautus for the Strasbourg Academie Theatre.

Prices are subject to change

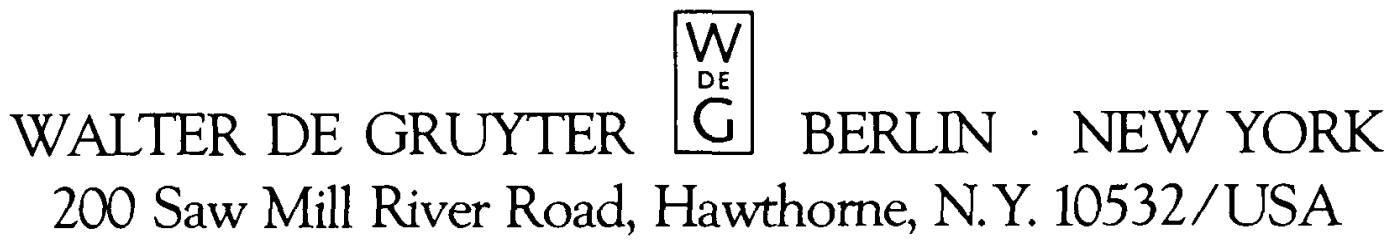









\section{undmost up to date The Best-Written_Text Package on the History of the English Language}

THE ROOTS OF MODERN ENGLISH, SECOND EDITION by L.M. Myers and Richard L. Hoffman. Cloth/321 pages/\$13.95

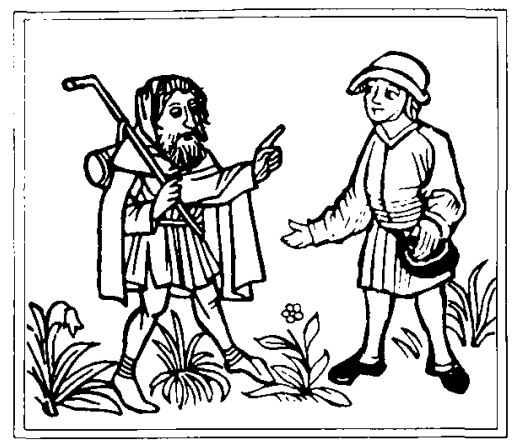

COMPANION TO THE ROOTS OF MODERN ENGLISH, SECOND EDITION by Richard L. Hoffman and L. M. Myers. Paper $/ 196$ pages $/ \$ 8.95 /$ with complimentary Answer Key.

Long admired for its intelligence, wit, and lucidity, THE ROOTS OF MODERN ENGLISH is now available in a new edition. Together with its workbook, COMPANION TO THE ROOTS OF MODERN ENGLISH, the text presents an unusual amount of Old and Middle English material, accompanied by a wide variety of aids to its understanding.

\section{JUST PUBLISHED!}

Bernstein, Carol L.: PRECARIOUS ENCHANTMENT: A READING OF MEREDITH'S POETRY ISBN 0-8132-0543-3

This study, the first modern book-length treatment of George Meredith's poetry, examines his complex conception of the self, his variations upon narrative forms, and his challenging style. Meredith emerges as a poet of distinction, one who may be easier to understand now than in his own time.

\section{Other Titles of Interest}

Cohen, Edward H.: Works and Criticism of Gerard Manley Hopkins: A Comprehensive Bibliography

(1969) 0-8132-0253-1 \$9.95

Crisafuli, Alessandro S. (ed.): Linguistic and Literary Studies in Honor of Helmut A. Hatzfield

(1964) 0-8132-0333-3

$\$ 25.00$
Mendeloff. Henry: A Manual of Comparative Romance Linguistics: Phonology and Morphology

(1970) 0-8132-0262-0 \$9.95

Sola-Solé, Josep M. et al. (eds.): Studies in Honor of Tatiana Fotich

(1973) 0-8132-0527-1

$\$ 12.00$

Send orders to our distributor:

International Scholarly Book Services, Inc.

P.O. Box 555

Forest Grove, Oregon 97116 


\section{The University of Tulsa's Graduate Faculty of Modern Letters \\ announces the establishment of the Center for the Study of Women's Literature and the appointment of Germaine Greer \\ as Professor of Modern Letters and Director of the Center}

The Center is to be an integral part of the University's Graduate Program in Modern Letters, offering courses which will complement the regular degree offerings at both the master's and the doctoral level. Besides the resident faculty, distinguished visitors will also be invited to teach, lecture, and carry on research in connection with the Center.

The aim of the Tulsa Center for The Study of Women's Literature is to provide the resources and environment for the development of a coherent and scholarly approach to the problems of description and evaluation of the vast body of literary work by women. The avenues of enquiry will be threefold: bibliographical, critical, and historical. $\square$ Critical editions of work by better-known women writers will be prepared and presented, definitive texts of important works established, and authentic texts of works now misattributed and virtually lost recovered. $\square$ Texts will be elucidated, and their relation to the mainstream of literary tradition explained with attention to influences both exerted and undergone, and with the aim of refining a critical vocabulary which is neither prejudiced nor propagandist. $\square$ Cultural conditions governing women's literary work, such as the attitude of the publishing industry, the vicissitudes of literary reputation and the direction of women's interest to specific literary forms and themes, will be researched and described.

one of the projects to be undertaken by the center is the publication of a semi-annual journal, Tulsa Studies in Women's Literature, under the editorship of Germaine Greer. Graduate students and other scholars working in the Center will have the opportunity to participate in the development of this journal.

All applicants to the center, whether degree candidates or post-doctoral scholars, will be expected to meet normal requirements for admission to the Graduate Program in Modern Letters. All those admitted, except post-doctoral researchers, will be expected to fulfill normal requirements for a degree. Professor Greer will be in residence during the fall term each year.

A limited number of fellowship appointments, entailing teaching, research or editorial responsibilities, will be available to graduate students participating in the Center.

$\square$ For further information and application materials please write: Gordon 0 . Taylor - Graduate Faculty of Modern Letters • University of Tulsa • 600 S. College Avenue - Tulsa, Oklahoma 74104 


\title{
SUMMER 1980 \\ LATIN/GREEK INSTITUTE
}

City University of New York-located in midtown Manhattan

\section{BASIC PROGRAM:}

2-3 years of college work in Latin or Greek in 11 weeks of total immersion. (No previous knowledge assumed.)

16 June-28 August

12 undergraduate credits (through Brooklyn College)

Language instruction; readings from antiquity through the Renaissance; archaic and koine texts
ADVANCED PROGRAM:

combines intensive upper-division reading instruction with graduate seminars.

7 July-26 August

6 graduate credits (through CUNY Graduate School)

TOPIC FOR 1980: ROMAN LOVE POETRY AND THE RISE OF EUROPEAN LOVE LYRIC

Ideal for persons in related fields who want an intensive experience with classical language and literature in one summer.

Faculty of 12 experienced college teachers available 24 hours a day (by phone when not in person)

Student/Faculty ratio: about $7: 1$

FOR INFORMATION AND APPLICATION FORMS write to:

Latin/Greek Institute, Room 1012 A

City University Graduate Center

33 West 42 Street

New York, N.Y. 10036

Telephone: (212) 790-4284 (10 A.M.-5 P.M. weekdays)

\section{SUMMER PROGRAMS IN FRANCE AVIGNON}

\begin{abstract}
Institute for American Universities, Chartered by the Regents of the University of the State of New York under the auspices of the University of Aix-Marseille, founded 1409
\end{abstract}

The Institute offers outstanding programs in southern France from mid-June to late July:

FRENCH LANGUAGE AND LITERATURE (in French), in Avignon, specializing in French Grammar, Composition, Conversation and Phonetics, (6 credit hours.) Students participate in the Theater Festivals in Avignon and Orange. 6 weeks. Tuition, Housing. Field Trips. Insurance: $\$ 745$

ART IN PROVENCE (a Fine Arts workshop in English), in Avignon, painting with European and American masters combining the best modern elements in European and American art. Subjects include the landscapes and historical sites in the region painted by Cézanne and Van Gogh. (6 credit hours.) 6 weeks. Tuition, Housing. Field Trips. Insurance: $\$ 745$

For further details write airmail to:

The Director

Summer Programs

27, place de l'Université

13625-Aix-en-Provence

France

Tel: (42) 23.39.35 




"A consistently lively, elegant, original work. Professor Undank's study of the transactions of Diderot's literary subjectivity and its world is at once erudite and critically acute: it is a truly significant contribution to literary studies."

Leo Bersani, Univ. of California, Berkeley
"The beauty of Undanks work appears not simply in its breath-taking style or in its sustained analyses but. more significantly, in its ability to highlight suggestively in passing more in a few lines than entire books do over many ponderous pages."

Daniel O'Hara, boundary 2

In the course of a phenomenological investigation which guides him through a reconsideration of mimesis and mimetic acts, of sentimentality and "sympathetic imagination." Undank studies the origins and ramifications of reactive shifts of consciousness in the work of Diderot and his contemporaries and, in the process, reveals the power structures underlying eighteenth-century rhetoric.

$\$ 10.95$ cloth $\$ 4.95$ paper

Orders may be placed through Coda Press, Inc., 700 W. Badger Rd., Suite 101, Madison, WI 53713. Mail order please include $\$ 1.00$ to cover postage and handling.

\section{Lively Literary Studies}

\section{A Roman Collection}

Stories, Poems, and Other Good Pieces

by the Writing Residents of

The American Academy in Rome

Miller Williams, editor. Through the eyes of such luminaries as John Hersey, Mary McCarthy, and William Styron, share the experience of living in the city the editor calls "the world's largest impromptu theater, wildest racetrack, most frustrating parking lot. . . " 368 pages April $\mathbf{\$ 1 2 . 5 0}$

\section{A Wild Civility}

Interactions in the Poetry

and Thought of Robert Graves

Patrick J. Keane. Keane sees Yeats as Graves's major literary relative; his treatment of their relationship reveals new insights into Graves's notorious hostility to Yeats. Keane stresses the poems from the 1920 s to the $1940 \mathrm{~s} .128$ pages May $\$ 6.95$ paper

\section{Protean Poetic}

The Poetry of Sylvia Plath

Mary Lynn Broe. Plath is demythologized by this study of her complete oeuvre, both published and unpublished, through Broe's concentration on her themes and techniques rather than on the lurid details of her life. 256 pages March \$16.00

\section{Of Earth and Darkness}

The Novels of William Golding

Arnold Johnston. The author demonstrates how Golding draws upon his own life and his wide-ranging literary and intellectual interests to create his strikingly original fiction, which often grows out of his rejection of earlier artists' ideas. 160 pages March \$13.95

\section{Money and Politics in Ibsen, Shaw, and Brecht}

Bernard F. Dukore. Dukore's work is structured around the ways the three writers treat issues and themes involving money, politics, or both, isolating the particular viewpoints from which each playwright treats capitalist society. 224 pages April \$15.95

University of Missouri Press, P.O. Box 1644, Columbia, Missouri 65205 


\section{Writing and Difference}

Jacques Derrida

Translated, and with an Introduction and Additional Notes, by Alan Bass

First published in 1967, Writing and Difference, a collection of Derrida's essays written between 1959 and 1966, has become a landmark of contemporary French thought.

Paper 362 pages $\$ 5.95$ February

\section{Northrop Frye on Culture and Literature}

A Collection of Review Essays

Edited and with an Introduction by Robert D. Denham

"There are not many critics whose twenty-year-old book reviews one can read with pleasure and instruction, but Frye is an exception to most rules. He combines a North American academic professionalism with a witty, apparently effortless fluency of style that one associates with the best English literary journalism." - David Lodge, New Statesman

Paper 272 pages $\$ 5.50$ February

\section{The Journey to the West}

Volume 1

Translated and Edited by Anthony C. Yu

This fantastic tale recounts the sixteen-year pilgrimage of the monk Hsuan-tsang (596-664), one of China's most illustrious religious heroes, who journeyed to India with four animal disciples in quest of Buddhist scriptures. For nearly a thousand years, his exploits were celebrated and embellished in various accounts, culminating in the hundred-chapter Journey to the West, which combines religious allegory with romance, fantasy, humor, and satire.

Paper 544 pages $\$ 8.95$ February

\section{The Schlemiel as Modern Hero}

Ruth R. Wisse

"A wonderfully intriguing study by a very gifted writer.... Wisse writes with insight, irony, and grace. The book is one of the year's unheralded pleasures."-Publisher's Weekly Paper 152 pages \$3.95 March

\section{The University of Chicago Press Chicago 60637}

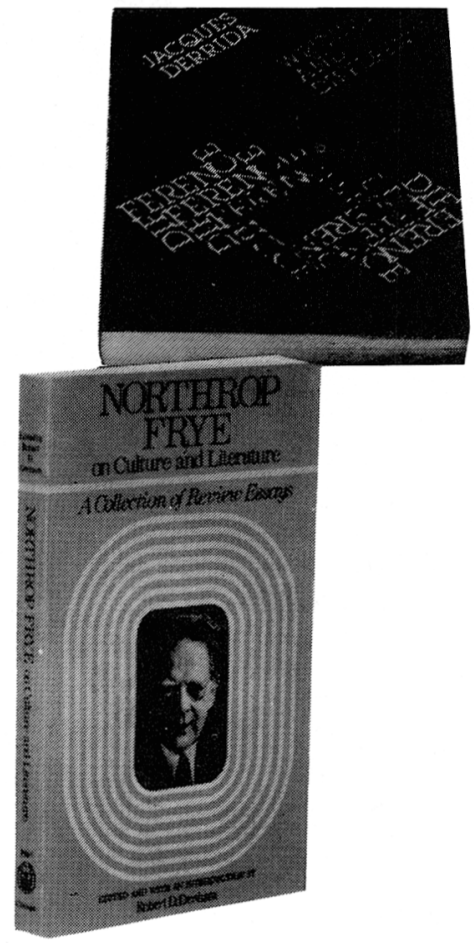

\section{The Novel before the Novel}

Essays and Discussions about the Beginnings of Prose Fiction in the West

Arthur Heiserman

"Arthur Heiserman has given us the best short study of ancient prose fiction in any language, scholarly, well-informed, concise, and extremely stimulating.... The vitality of invention and formal experiment within the genre of ancient fiction has never been revealed so freshly as in this book.... A lasting monument to its author." -Brian Vickers, Times Literary Supplement

Paper 248 pages $\$ 7.00$ February

\section{Modern Latin American Narratives}

The Dreams of Reason

Alfred J. Mac Adam

Focusing on writings by Machado de Assis, Adolfo Bioy Casares, Julio Cortázar, Gabriel García Márquez, and José Donoso, among others, Mac Adam persuasively develops the controversial thesis that satire, not the novel, is the dominant form of the Latin American narrative.

Paper 160 pages $\$ 3.95$ February 


\section{"One of the great scholarly enterprises of our time."}

- Choice

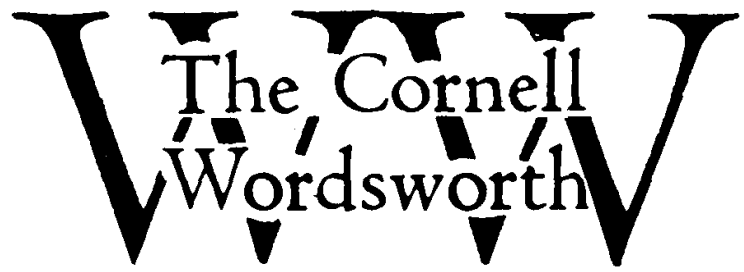

\section{General Editor: STEPHEN PARRISH}

Wordsworth's practice of leaving his long poems unpublished for years after their completion, and his lifelong habit of revision, have obscured the original - often the best - versions of those poems. This series, inaugurating a fresh approach to Wordsworth scholarship, presents for the first time full and accurate texts of Wordsworth's long poems, together with all variant readings from original drafts down to the final printing in the poet's lifetime, or the first posthumous printing.

\section{The Ruined Cottage and The Pedlar}

Edited by JAMES BUTLER. "Good books, like good characters, are difficult to write about-and good editions are a great deal more so. In his presentation of the different stages and versions of The Ruined Cottage for the Cornell Wordsworth, James Butler has done an exemplary job.... His introduction, and the various notes and headnotes, are clear and to the point. The complicated story of the origins and development of The Ruined Cottage is told simply and told concisely. Mr. Butler's prose is lucid, his evidence is honestly presented, and his judgments are right." - JONATHANWORDSWORTH, The Wordsworth Circle.

\section{The Prelude, 1798-1799}

Edited by STEPHEN PARRISH. "The formidable resources of modern scholarship are on impressive display in this, the second volume of 'The Cornell Wordsworth' - an undertaking that will unquestionably become the standard edition of Wordsworth's long poems... No one can henceforth write on any portion of The Prelude without consulting this work, which brings us excitingly close to Wordsworth's creative process."-Choice.

$\$ 19.50$

\section{The Salisbury Plain Poems of William Wordsworth}

Edited by STEPHEN GILL. "Stephen Gill has produced a wonderful edition: complex yet lucid, and with a high degree of accuracy."-PAULF. BETZ, The Wordsworth Circle.

$\$ 20.00$

\section{Home at Grasmere}

Edited by BETH DARLINGTON. The ingenuity, critical tact, scholarly thoroughness, and yes, the sheer monumental labor behind this book once again amply justify the series of which it now forms a distinguished part."-Modern Language Notes.

$\$ 25.00$

Soon to be published...

The Borderers Edited by ROBERT OSBORN Benjamin the Waggoner Edited by PAUL F. BETZ
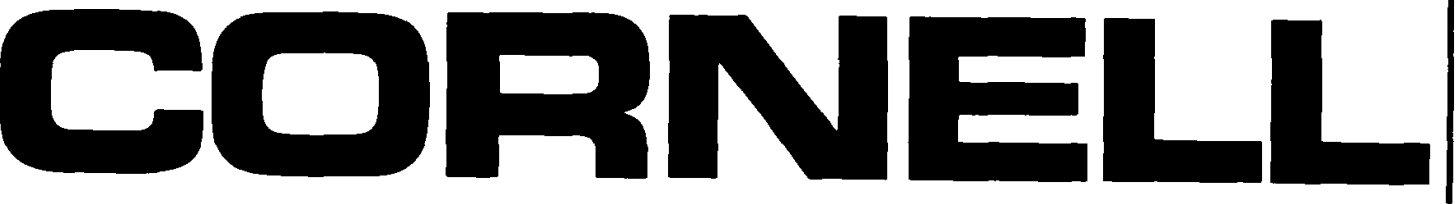

UNIVERSITY PRESS, P.O. Box 250, Ithaca, New York 14850 